\title{
Microbial mats in French Polynesia and their biotechnological applications
}

\author{
Jean Guézennec ${ }^{\mathrm{a}, 1}$, Xavier Moppert ${ }^{\mathrm{b},{ }^{*}}$, , Gérard Raguénès $^{\mathrm{a}, 1}{ }$, Laurent Richert ${ }^{\mathrm{b}}$, Bernard Costa $^{\mathrm{b}}$ and \\ Christelle Simon-Colin ${ }^{a, 1}$
}

a IFREMER Centre de Brest, BRM/BMM; BP 70; 29280 Plouzané, France
b Pacific Biotech SAS BP 140 289, 98701 Arue (Tahiti), French Polynesia

* Corresponding author : X. Moppert, Tel.: +689 5420 69; fax: +689 4257 60, email address : xmoppert@pacific-biotech.pf

${ }^{\mathrm{i}}$ Tel.: +33 0 298224528; fax: +33 0298224757.

\begin{abstract}
:
It is well known that microorganisms well-adapted to survival in extreme ecosystems could be considered as new sources of biomolecules that have biotechnological importance. On French Polynesian atolls, microbial mats are developing in water ponds exposed to fluctuations in physical and chemical parameters. In these microbial mats, which are called "kopara" by the inhabitants, bacteria coexist with cyanobacteria, and a synergistic relationship may exist between these two types of living microorganisms. A large number of cyanobacteria and bacteria have been isolated from different mats. Under laboratory conditions, these microorganisms were shown to produce various exopolymers, including exopolysaccharides and poly- $\beta$-hydroxyalkanoates, along with pigments for further commercial developments. This manuscript gives an overview of substances isolated and characterized from these bacteria and cyanobacteria and discusses their potential applications in biotechnology.
\end{abstract}

\section{Research highlights}

"Kopara" sampling. New microorganisms isolation. EPS- and PHA-production screening. Labscale production. Biological activities and chemical properties screening. Research \& Development studies.

Keywords: Microbial mats; Kopara; Biopolymers; Exopolysaccharides; Poly- $\beta$-hydroxyalkanoates 


\section{Introduction}

In the past few years, a remarkable number of structurally unique and highly bioactive metabolites have been isolated from marine bacteria. Though there is a long, successful history of antibiotics of terrestrial origin, the search for marine microbial metabolites remains a relatively untouched subject, even today. Biotechnology has been recognized as one of the most promising technologies for the 21st century [1]. Life originated in the sea, and the incredible diversity of ocean life is linked to the relatively prolonged evolutions and adaptations of marine organisms over their land counterparts. Developing novel drugs for treating diseases, such as cancer and neurodegenerative diseases, producing diagnostic devices (biosensors) for monitoring health, discovering new types of composite materials, biopolymers and enzymes, finding new ways of harnessing bioenergy, ensuring sustainable and safe aquaculture and fisheries and providing new approaches to protect and manage marine environments make up just a small subset of the possibilities of marine biotechnology.

Microbial mats are laminated communities primarily composed of phototrophic and chemotrophic prokaryotes. The vertical stratification of such communities is a response to the organisms' physiological requirements to the gradients of light, oxygen, redox potential, sulfide and $\mathrm{pH}$. These microbial mat ecosystems require nitrogen fixation from nitrogen fixing cyanobacteria to develop [2]. Such microbial mats are found in many lagoons in Baja California [3], lakes in the Sinaï, Egypt [4] and still waters in Spain [5]. Benthic microbial communities, growing as gelatinous deposits several tens of centimeters thick, are also present in some shallow lakes on the rims of some French Polynesian atolls (Fig. 1). The inhabitants call these benthic microbial communities "kopara" [6]. "Kopara" mats are characterized by varied physical and chemical parameters, with $\mathrm{pH}$ values ranging from 6 to 10.5 , salinity levels ranging from $5 \mathrm{~g} / \mathrm{l}$ to $42 \mathrm{~g} / \mathrm{l}$, temperatures ranging from $20^{\circ} \mathrm{C}$ during the night up to $42^{\circ} \mathrm{C}$ around mid-day [7] and light intensities varying from one site to another. In such unusual environments, bacteria co-exist with cyanobacteria and may form a synergistic relationship.

From the discoveries of novel biopolymers and biomolecules of biotechnological significance, it is now widely accepted that microorganisms from unusual environments not only provide valuable resources for exploiting novel biotechnological processes but also serve as models for investigating how biomolecules are stabilized when subjected to changing conditions [8]. In this regard, microbial mats offer new sources of fascinating microorganisms well-adapted to these changing environments. Over the past 10 years, an increasing number of new mesophilic bacteria and cyanobacteria species have been isolated from these Polynesian ecosystems. This new microbial diversity includes strains able to produce novel molecules, such as biopolymers, pigments and other bioactive molecules.

This paper examines the discovery and applications of innovative biopolymers produced under laboratory conditions by microorganisms isolated from different microbial mats present on Polynesian atolls.

\section{Microbial community structure}

The microbial community structure in "kopara" mats is dominated by only a few functional groups of microorganisms, which include cyanobacteria, with the predominating genera Phormidium and Scytonema, sulfurous and non-sulfurous photosynthetic bacteria, sulfatereducing bacteria in the deeper layers and Desulfovibrio and Desulfobacter species $[9,10]$. Other microorganisms isolated include the following: Chromatium sp., Thiocapsa, Thiocystis spp., Blastochloris spp., Rhodobacter spp. and Rhodospirillum spp., along with heterotrophic bacteria belonging to the Pseudomonas, Alteromonas, Paracoccus and Vibrio genera [1114]. 


\section{Vertical distribution of exopolysaccharides in different mats}

Various macromolecules, including polysaccharides, proteins, lipids and nucleic acids, form the architectural matrix in the intercellular space of microbial biofilms and unattached aggregates and have been characterized from the environment of the mats (Fig. 2) [10]. Extracellular polymers help microorganisms compete and survive in changing environmental conditions by altering the physical and geochemical microenvironment around the cell [15]. In most mats analyzed to date, the highest levels of exopolysaccharides, up to $50 \mathrm{mg} \mathrm{EPS} / \mathrm{g}$ of dry weight, were found in the uppermost layers (Table 1, Fig. 3). The exopolymer proportion decreased markedly with increasing depth and was negligible beyond $8 \mathrm{~cm}$. The highest levels of exopolysaccharides were clearly related to the highest biomass and presence of cyanobacteria.

\section{EPS fractions analysis}

The gross chemical composition of the crude exopolysaccharide fractions showed that neutral sugars predominated in all samples. However, all exopolysaccharides were polyanionic in nature, due to the presence of uronic acids with concentrations ranging from $11 \%$ to $18 \%$. The occurrence of uronic acids is, to a great extent, responsible for the binding of heavy metals and radionuclides in the mats [16]. Within the different mats, the exopolysaccharide composition showed no marked changes with depth. Glucose, galactose and mannose predominated as neutral sugars with equal amounts in all samples. In addition, 6-deoxy hexoses, such as rhamnose, fucose and xylose, were found at lower concentrations. Only traces of arabinose were observed. Glucuronic and galacturonic acids were the only uronic acids identified in these fractions, with the former predominating [10].

\section{EPS producing microorganisms}

Using cultures involving laboratory-closed photobioreactors, a partial screening performed on some Polynesian microbial mats led to the discovery of the following six cyanobacterial isolates: Chroococcus submarinus (Hansgirg) Kovacik, Johannesbaptistia pellucida (Dickie) Taylor et Drouet, Rhabdoderma cf. rubrum (Alvik) Komarek et Anagnostidis, Geitlerinema (Oscillatoria) sp., Lyngbya aestuarii (Mertens) Liebman, and Plectonema (Leptolyngbya) cf. golenkinianum Gomont [17]. Under unbalanced growth conditions, these strains were shown to produce both capsular and released EPS. Both exopolymers are characterized by high proportions of neutral sugars and a significant number of sulfate groups. Additional experiments are in progress to evaluate the biotechnological potential of these cyanobacterial exopolysaccharides.

In addition to cyanobacteria and both sulfurous and non-sulfurous photosynthetic bacteria predominating in the different microbial mats, mesophilic bacteria originating from these ecosystems were also able to produce novel exopolymers under laboratory conditions. From a partial screening of the collection of microorganisms (up to 1,100 isolates from different mats), a number of microbial exopolymers with interesting chemical and rheological properties have been characterized. Bacteria associated with these changing conditions have demonstrated their abilities to produce unusual extracellular polysaccharides in an aerobic, carbohydrate-based medium. Thusfar, the following four main EPS producers have been identified: Pseudomonas, Alteromonas, Paracoccus and Vibrio. Only a few polymers so far have been fully characterized, but considerable information related to the chemical composition of other polymers and their rheological and heavy metal binding properties has been obtained. Most of these polymers have uronic acid content ranging from $6 \%$ to $28 \%$ and high molecular weights of up to $10^{6} \mathrm{~g} / \mathrm{mol}$. Neutral sugars are present in various ratios, 
with rhamnose, fucose, galactose and glucose predominating. The occurrence of amino sugars, such as $\mathrm{N}$-acetyl galactosamine and $\mathrm{N}$-acetyl glucosamine, along with sulfate and acyl groups, such as acetate, lactate and succinate, is also of great importance for cosmetic and other applications.

So far, the most remarkable result of this screening was the discovery of Paracoccus zeaxanthinificiens subsp. payriae, a bacterium, under laboratory conditions. This bacterium is able to produce a water-soluble and highly sulfated exopolysaccharide, along with a nonwater soluble macromolecule that was assumed to be a glycoprotein $[11,18]$. The chemical composition of the water-soluble exopolysaccharide appeared to be different from that produced by other bacteria from similar environments. The most important feature is undoubtedly its high sulfate content, which can be up to $29 \% \mathrm{w} / \mathrm{w}$, in its native state (Fig. 4). The biosynthesis of such a highly sulfated exopolysaccharide by a marine bacterium has, to the extent of our knowledge, never been reported in the literature. The natural occurrence of sulfate is known to improve the biological activity of some polysaccharides with antiviral activity, including those with activity against the human immunodeficiency virus. In addition, certain biological activities, such as blood coagulation, are influenced by the sulfate content and position on some polysaccharides [19-21]. In this regard, the newly discovered EPS, referenced RA29 and belonging to the Vibrio sp., deserves special attention (Table 2).

Another bacterium was also isolated in the lagoon of Moorea Island (French Polynesia), and it is referred to as strain MO 245, also belonging to the Vibrio sp.. During stationary phase growth in batch cultures in the presence of glucose, this bacterium produced an EPS characterized by equal amounts of uronic acid and hexosamine ( $\mathrm{N}$-acetyl glucosamine and $\mathrm{N}$-acetyl galactosamine) and traces of galactose. This exopolymer appeared to have very similar properties to those of another exopolymer synthesized by a bacterium originating from a deep-sea hydrothermal vent [22,23], i.e. Vibrio diabolicus, which showed innovative properties in terms of tissue regeneration [24-26].

\section{Biopolymers of industrial interest}

The broad array of microbial activities within mats suggests that the isolates may have a number of important biotechnological applications. In addition to bioremediation, aquaculture and energy production are promising uses [27]. Bacterial exopolymers are also fascinating sources of macromolecules of biotechnological importance. Due to their many interesting physical and chemical properties, such as ability to stabilize, suspend, thicken, gel, coagulate, form films and retain water, polysaccharides have found applications in many industrial sectors (e.g. detergent, textile, adhesives, paper, paint, food and beverage industries; pharmaceutical and cancer therapies; drug delivery; oil and metal recovery in the mining industry; industrial waste and formulation of cell culture media) $[20,28]$.

Another industrial sector interested in the discovery and development of new polysaccharides is the cosmetics industry, which is searching for new molecules from natural environments. Consumer concern about the unwanted signs of aging and stress-related effects has led to the development of products for skin firming, skin lightening, moisturizing, smoothing, line removing, anti-aging, skin repair, skin protecting, and more. Polysaccharides, along with vitamins, proteins, peptides, enzymes, coenzymes and pigments play important roles in such so-called anti-aging products. Three EPSs originating from these microbial mats have been already commercialized in this area of anti-radical, texturing and moisturizing agents. A highly sulfated exopolysaccharide, produced by Paracoccus zeaxanthificiens subsp. payriae, either in its native state or following strong depolymerizarion (up to $15,000 \mathrm{Da}$ ), was shown to strongly inhibit the secretion of the lipoprotein lipase, a hydrolytic enzyme involved in the hydrolysis of very low density proteins and chylomicrons into triglycerides [29]. Tests were performed on cultivated adipocytes (3T2-L1) [30]. This particular exopolymer is under commercial development in the cosmetic field (data not shown). 
Water pollution due to toxic heavy metals remains a serious environmental and public health problem. Heavy metals are not biodegradable and accumulate in living organisms, causing serious problems and diseases. Under public and media pressure, different states have progressively introduced stricter regulations with regards to metal discharges and the treatment of industrial operations. Biosorption may be defined as a process by which metal is sequestered by chemical sites naturally present in the biosorbents. Compared to more conventional technologies, including, but not limited to, chemical precipitation, chemical oxidation, electrochemical treatment and reverse osmosis ion exchange, biosorption can be considered an alternative technology on par with these more conventional approaches. One advantage of biosorption is that it is cost-effective when inexpensive biosorbents are employed. Inexpensive biosorbents could include those that are either abundant in nature, such as seaweeds or other biomasses, or products obtained by fermentation of microorganisms, such as exopolymers. EPS produced under laboratory conditions by Paracoccus zeaxanthificiens subsp. payriae and isolated from a microbial mat, exhibited a very high binding capacity for both copper (up to $9.84 \mathrm{mmol} / \mathrm{g}$ ) and iron (II) (up to 6.9 $\mathrm{mmol} / \mathrm{g}$ ) salts. It may be expected that other high uronic acid-containing exopolymers (Table 2) may find applications in heavy metal and radionuclide waste cleanup [31]. Experiments are under progress to select the appropriate exopolymers for different types of applications. Research in this area will be important for the development of a low-cost biosorbent used in its native state or as a modified polysaccharide-based material.

\section{Bacterial Polyhydroxyalkanoates (PHAs)}

Polyhydroxyalkanoates (PHAs) are biopolymers produced by a wide variety of bacteria as carbon and energy storage materials in response to the presence of excess carbon and to the restriction of one growth-limiting nutrient (mostly nitrogen) [32,33]. They are deposited intracellularly in the form of inclusion bodies ("granules") and may account for up to $90 \%$ of cellular dry weight. The monomeric composition of PHAs depends on the bacterial strain and on the carbon source supplied. PHAs comprise a large class of polyesters and can be divided into the following three groups, depending on the number of carbon atoms in the monomeric units: short-chain-length PHAs (3-5 carbon atoms, "scl PHAs"), medium-chainlength (6-15 carbon atoms, "mcl PHAs") and long-chain-length (more than 15 carbon atoms, "Icl PHAs"). Typically, PHAs with short-chain-lengths, such as poly-3-hydroxybutyrate (PHB), are highly crystalline, stiff, brittle and poorly elastic. Longer-chain-length PHAs are semi-crystalline elastomers with low melting points and low tensile strengths, and they require high elongations to break. Owing to their inherent biodegradability and biocompatibility, PHAs have attracted industrial interest and have been extensively studied in the last two decades [34-38]. PHAs can be produced from natural renewable carbon sources and are considered alternatives to non-biodegradable plastics produced from fossils oils. Thus, PHAs can be used to tackle the problems of plastic waste in the future. By means of grafting reactions, copolymerizations, chlorinations, epoxidations, carboxylations, etc., functionalized PHAs can be obtained. Because of the many ways in which functionalized PHAs can be obtained, PHAs are diverse in their industrial applications. Applications exist in medical implants, pin and dental sutures, drug delivery systems, ophthalmology, textiles, industrial and institutional uses, hygiene products, agricultural products, bag composting, food packaging and tissue engineering [3941].

Despite the large variety of novel and recently discovered PHAs, the high production cost of PHAs has limited their wide acceptance in the market. There are a number of challenges to their more widespread application for industrial processes. Commercial development has to undergo a significant decrease in the cost of production by using cheaper carbon substrates, such as those obtained from agricultural by-products or streams [42-46], optimizing fermentation strategies and looking for alternative recovery methods to solvent extraction. With all these advances, it is likely that PHAs will become a major biodegradable plastic with 
a wide range of applications in the near future. PHAs may also be able to eliminate disposal problems and environmental hazards prevalent with petroleum derived polymers.

Little is known about the ecological role of PHAs in the indigenous bacterial populations of natural ecosystems. Interestingly, PHAs have been detected in many natural environments, including deep-sea hydrothermal sediments [47] and microbial mats of the Great Sippewisset Salt Marsh on Cape Cod (USA) and the Ebro Delta in Spain $[48,49]$. Interesting structures of both scl- and mcl- PHAs have been identified as synthesized by bacteria isolated from microbial mats. Additional screenings of the whole bacterial collection are in progress.

An aerobic, mesophilic, heterotrophic bacterium, Pseudomonas guezennei, was isolated from a "kopara" mat located on the atoll of Rangiroa. Under laboratory conditions, this bacterium produced a novel mcl PHAs mainly composed of 3-hydroxydecanoate (3HD) (64 $\mathrm{mol} \%)$ and 3-hydroxyoctanoate (3HO) (24 mol \%), using glucose as its sole carbon source [12]. Interestingly, rRNA group I Pseudomonas species are well known to biosynthesize mcl PHAs, but relatively few are able to produce mcl PHAs using glucose as sole carbon sources for both growth and polymer accumulation [50]. Additional experiments showed that, depending on the nature of the carbon source supplied, this bacterium was also capable of producing a variety of mcl PHAs via de novo fatty acid biosynthesis [13].

Pseudomonas guezennei subsp. tikehau isolated from a microbial mat on the atoll of Tikehau was able to produce a high yield of an elastomeric PHAs copolymer using coconut oil as the sole carbon source [51]. The melting and glass transition temperatures were $45^{\circ} \mathrm{C}$ and $46^{\circ} \mathrm{C}$, respectively. The production of PHAs began after $6 \mathrm{~h}$ in oil-enriched medium and increased up to $63 \%$ of cellular dry weight after $36 \mathrm{~h}$ (Fig. 5).

Another strain, Paracoccus zeaxanthinifaciens subsp. payriae, was shown to synthesize large amounts of poly-3-hydroxybutyrate (up to $90 \%$ of cell volume) and copolymers of $\mathrm{P}(3 \mathrm{HB}-\mathrm{Co}-3 \mathrm{HV})$, with different ratios of 3-hydroxyvalerate (3HV) and 3-hydroxybutyrate (3HB) depending on the carbon source supplied [18]. More recently, Pseudomonas raguenesii isolated from a mat located of the Tetiaroa atoll was demonstrated to produce different $\mathrm{mcl}$ PHAs from various by-products of the cosmetic manufacturing. This finding lead to the discovery of an interesting class of thermoelastomers [14]. Molecular weights ranged from $175,000 \mathrm{~g} / \mathrm{mol}$ to $35,000 \mathrm{~g} / \mathrm{mol}$, with polydispersity values lower than 2 . Original compositions were obtained, which included high levels of unsaturated monomers. The unsaturated $\mathrm{mcl}$ PHAs can be easily modified to produce functionalized polymers and constitute a promising approach to expend bacterial polyesters to be used in the medical and environmental areas [52,53].

\section{Pigments}

Microbial communities in the mats are stratified, and the resulting lamination is easily recognized by the striking differences in colors (green, red, orange, pink or white) that result from the different pigments of contribution organisms (Fig. 3). Up to 29 different pigments have been analyzed in some microbial mats pigments, with $\beta$ carotene, myxoxanthophyll bacteriochlorophyll a and chlorophyll a predominating [9]. The occurrence of a significant amount of zeaxanthine is also of interest. A bacterium described as Paracoccus zeaxanthinifaciens subsp. payriae and isolated from such microbial mats was shown to produce large amounts of a yellow-orange pigment $[11,18]$. High-performance liquid chromatography and circular dichroic analyses indicated that this pigment mainly consisted of pure $(>98 \%, w / w)$ isomer (3R, 3'R)-zeaxanthin. This finding is one of the first steps in assessing the metabolite production potential of this strain, which, under similar growth conditions, also produces a highly sulfated exopolysaccharide of biotechnological interest [31]. Zeaxanthin ( $\beta, \beta$-carotene-3, 3'-diol) is a lipophilic yellow carotenoid useful in the pigmentation of foodstuffs and cosmetics. Zeaxanthin and lutein are the two pigments present in the macula membrane, where they play protective roles against light and oxygen aggression [54]. Zeaxanthin has a remarkable potential for use in pharmaceuticals because it 
prevents age-related macular degeneration (AMD), which can lead to blindness [55]. Nevertheless the (3R, 3'R) stereoisomer of zeaxanthin has antioxidant abilities and is present in large amounts in the macula [56].

\section{Prospect and conclusions}

One of the most promising and exciting aspects of marine biotechnology is bioprospection, which is the search for new and innovative natural compounds that can be used as novel drugs, healthcare products, agrochemicals for crop protection and biopolymers. However, the major biodiversity in the oceans does not reside in plants and animals but in the tremendous diversity of microbial life that can be found in diverse marine environments. Microorganisms continue to provide an exciting source of novel bioactive molecules. Interest in this particular field is due in part to the ability of many microorganisms to produce these natural compounds through fermentation, thus minimizing supply problems. In comparison to the search for new metabolites from terrestrial sources, the search for new metabolites from marine microorganisms is only beginning and can be expected to satisfy the demand for new metabolites from terrestrial biological sources in the near future. To achieve success in marine biotechnology, some obstacles to the discovery and cultures of these organisms must be overcome. There is a need to design new approaches to isolate and culture new organisms. Metagenomics, through access to the huge reservoir of uncultivated and hidden bacteria, opens the door to yet another untapped source of bioactive compounds. Undoubtedly, microorganisms, whose huge genetic and biochemical diversity is only beginning to be explored, looks likely to become rich sources of novel chemical entities for new drugs.

Although the future is unpredictable, it is likely that biotechnology, primarily marine biotechnology, will play a much more significant role in the 21st century than it did during the last century. One of the most exciting aspects of marine biotechnology is exploring untapped ecosystems. The number of novel compounds will continue to grow as new discoveries will be made in diverse marine ecosystems.

\section{Acknowledgments}

This study was financially supported by PACIFIC BIOTECH SAS (Arue, Tahiti, French Polynesian). The authors would like to thank Tea Frogier, from the Research Ministry of French Polynesian, and Frederics Teriiatetoofa, the Tikehau Island's mayor, for his help during the sampling campaign on the island.

\section{References}

[1] Bull AT, Ward AC, Goodfellow M. Search and Discovery Strategies for Biotechnology: the Paradigm Shift. Microbiol Mol Biol Rev 2000;64:573-606.

[2] Stal LJ, Grossberger S, Krumbein WE. Nitrogen fixation associated with the cyanobacterial mats of a marine laminated microbial ecosystem. Mar Biol 1984;82:217-224.

[3] Stolz ST. The microbial community at Laguna Figueroa, Baja California Mexico: from miles to microns. Orig Life Evol Biosph 1985;15:347-52. 
[4] Teske A, Ramsing NB, Habicht K, Fukui M, Küver J, Jørgensen BB, Cohen Y. Sulfatereducing bacteria and their activities in cyanobacterial mats of solar lake (Sinai, Egypt). Appl Environ Microbiol 1998;64:2943-2951.

[5] Mir J, Martinez-Alonso I, Esteve I, Guerrero R. Vertical distribution and microbial assemblage of a microbial mat in the Ebro Delta (Spain). FEMS Microbial Ecol 1991;86:59-68.

[6] Trichet $J$. Etude des premiers stades d'évolution de la matière organique dans des mares en milieu récifal (Polynésie française). Adv in Org Geoch 1970;3:265-284.

[7] Defarge C, Trichet J, Maurin A, Hucher M. Kopara in Polynesian atolls: early stages of formation of calcareous stromatolites. Sedimen Geol 1994;89:9-23.

[8] Knigth V, Sanglier JJ, DiTullio D, Bracelli S, Bonner P, Waters J, Hugnes D, Zhang L. Diversifying microbial natural products for drug discovery. Appl Microbiol Biotechnol 2003;62: 446-458.

[9] Mao Che L, Andrefouët S, Bothorel V, Guézennec M, Rougeaux H, Guézennec J, Deslandes E, Trichet J, Matheron R, Le Campion T, Payri C, Caumette P. Physical, chemical, and microbiological characteristics of microbial mats (kopara) in the South Pacific atolls of French Polynesia. Can J Microbiol 2001;47:994-1012.

[10] Rougeaux H, Guezennec M, Mao Che L, Payri C, Deslandes E, Guezennec J. Microbial communities and exopolysaccharides from polynesian mats. Mar Biotechnol 2001;3:181-187.

[11] Raguénès G, Moppert X, Richert L, Ratiskol J, Payri C, Costa $B$, Guézennec J. A novel exopolymer-producing bacterium, Paracoccus zeaxanthinifaciens subsp. payriae, isolated from a "kopara" mat located in Rangiroa, an atoll of French Polynesia. Curr Microbiol 2004;49:145-151.

[12] Simon-Colin C, Alain K, Colin S, Cozien J, Costa B, Guézennec J, Raguénès G. A novel mcl PHA-producing bacterium, Pseudomonas guezennei sp. nov., isolated from a "Kopara" mat located in Rangiroa, an atoll of French Polynesia. J Appl Microbio 2008a;104:581-586.

[13] Simon-Colin C, Raguénès G, Costa B, Guezennec J. Biosynthesis of novel medium chain length poly-3-hydroxyalkanoates by Pseudomonas guezennei from various carbon sources. Reac Func Pol 2008b;68:1534-1541.

[14] Simon-Colin C, Alain K, Raguénès G, Schmitt S, Kervarec N, Gouin C, Crassous P, Costa B, Guezennec J. Biosynthesis of medium chain length poly(3-hydroxyalkanoates) (mcl PHAs) from cosmetic co-products by Pseudomonas raguenessii sp. nov., isolated from Tetiaroa, French Polynesia. Biores Techol 2009;100:6033-6039.

[15] Wingender J, Neu TR, Flemming HC. What are bacterial extracellular polymer substances? In: Wingender NT, Flemming J editors. Microbial Extracellular Polymer Substances. Berlin: Springer; 1999. p. 1-19.

[16] Jehl C. Les mattes algaires cyanobactériennes (kopara) des atolls des Tuamotu: biochimie, productivité et signification écologique. Insertion dans un modèle de phosphatogénèse. French Polynesia : Univeristé de la Polynésie Française ; Ph.D. thesis ; 1995. p.318. 
[17] Richert L, Golubic S, Le Guédès R, Ratiskol J, Payri C, Guezennec J. Characterization of exopolysaccharides produced by cyanobacteria isolated from Polynesian microbial mats. Curr Microbiol 2005;51:379-384.

[18] Moppert X. Etudes et valorisation de metabolites biosynthétisés par une souche bactérienne, isolée de tapis microbiens «kopara» de Rangiroa (Tuamotu, Polynésie Française). French Polynesia: Univeristé de la Polynésie Française ; Ph.D. thesis ; 2006. p.214.

[19] Colliec-Jouault S, Chevolot L, Helley D, Ratiskol J, Bros A, Sinquin C, Roger O, Fisher AM. Characterization, chemical modifications and in vitro anticoagulant properties of an exopolysaccharide produced by Alteromonas infernus. Biochim Biophys Acta 2001;1528:141-151.

[20] Colliec-Jouault S, Zanchetta P, Helley H, Ratiskol J, Sinquin C, Fischer AM, Guézennec J. Exopolysaccharides produced by bacteria isolated from deep-sea hydrothermal vents: new agents with therapeutic potential. Pathol Biol 2004;52:127-130.

[21] Weiner R, S Langille, Quintero E. Structure, function and immunochemistry of bacterial exopolysaccharides. J Ind Microbiol 1995;15:339-346.

[22] Raguénès G, Christen R, Guézennec J, Pignet P, Barbier G. Vibrio diabolicus sp. nov., a new polysaccharide-secreting organism isolated from a deep-sea hydrothermal vent polychaete annelid, Alvinella pompejana. Int J Syst Bacteriol 1997;47:989-995.

[23] Rougeaux H, Kervarec N, Pichon R, Guézennec J. Structure of the exopolysaccharide of Vibrio diabolicus isolated from a deep-sea hydrothermal vent. Carbohyd Res 1999;322:4045.

[24] Zanchetta P, Guézennec J. Surface Thermodynamics of osteoblats: Relation between hydrophobicity and bone active materials. Colloids Surf B Biointerfaces 2001;22(4):301-307.

[25] Zanchetta P, Lagarde N, Guézennec J. A new bone-healing material: A hyaluronic acidlike bacterial exopolysaccharide. Calcif Tissue Int 2003a;72:74-79.

[26] Zanchetta P, Lagarde N, Guézennec J Systematic effects on bone healing of a new hyaluronic acid-like bacterial exopolysaccharide. Calcif Tissue Int 2003b;73:232-236.

[27] Bender J, Philipps P. Microbial mats for multiple applications in aquaculture and bioremediation. Bioresour Technol 2004;94:229-238.

[28] Sutherland, IW. Products of primary metabolism. In Rehm HJ and Reed G editors. Biotechnology Second, completely revised edition. Weinheim, Germany: VCH; 1996;6:613-657.

[29] Patten RL, Hollenberg $\mathrm{CH}$. The mechanism of heparin stimulation of rat adipocyte lipoprotein lipase. J Lipid Res 1969;10:374-382.

[30] Querfeld U, Hoffman MM, Klaus G, Eifinger F, Ackerschott M, Michalk D, Kern PA. Antagonistic effects of vitamin $D$ and parathyroid hormone on lipoprotein lipase in cultured adipocytes. J Am Soc Nephrol 1999;10:2158-2164.

[31] Moppert X, Le Costaouec T, Raguénès G, Simon-Colin C, Crassous $P$, Costa $B$, Guézennec J. Investigation into the uptake of copper, iron and selenium by a highly sulphated bacterial exopolysaccharide isolated from microbial mats. J Ind Microbiol Biotechnol 2009;36:599-604. 
[32] Anderson A J, Dawes EA. Occurrence, metabolism, metabolic role, and industrial uses of bacterial polyhydroxyalkanoates. Microbiol Rev 1990;54:450-472.

[33] Timm A, Steinbüchel A. Formation of polyesters consisting of medium-chain-length 3hydroxyalkanoic acids from gluconate by Pseudomonas aeruginosa and other fluorescent Pseudomonads. Appl Environ Microbiol 1990;56:3360-3367.

[34] Braunegg G, Lefebvre G, Genser KF. Polyhydroxyalkanoates, biopolyesters from renewable resources: Physiological and engineering aspects. J Biotechnol 1998;65:127-161.

[35] Hankermeyer CR, Tjeerdema RS. Polyhydroxybutyrate: plastic made and degraded by microorganisms. Rev Environ Contam Toxicol 1999;159:1-24.

[36] Hocking PJ, Marchessault RH. Biopolyesters. In: Griffin GJL editor Chemistry and technology of biodegradable polymers, 1st Edn. London: Chapman \& Hall; 1994. p. 48-96.

[37] Huijberts GNM, Eggink G, De Waard P, Huisman GW, Witholt B. Pseudomonas putida KT2442 cultivated on glucose accumulates poly(-3-hydroxyalkanoates) consisting of saturated and unsaturated monomers. Appl Environ Microbiol 1992;58:536-544.

[38] Steinbüchel A, Valentin HE. Diversity of bacterial polyhydroxyalkanoic acids. FEMS Microbiol Lett 1995;128:219-228.

[39] Chen GQ, Wu Q. The application of polyhydroxyalkanaotes as tissue engineering materials. Biomaterials 2005;26:6565-6578.

[40] Pouton CW, Akhtar S. Biosynthetic polyhydroxyalkanoates and their potential drug delivery. Adv Drug Deliv Rev 1996;18:133-162.

[41] Williams SF, Martin DP, Horowitz DM, Peoples O. PHA applications: addressing the price performance issue: I. Tissue engineering. Int J Macromol 1999;25:111-121.

[42] Ashby RD, Solaiman DKY, Foglia TA. Bacterial poly(hydroxyalkanoate) polymer production from the biodiesel co-product stream. J Polym Environ 2004;12(3):105-112.

[43] Ashby RD, Solaiman DKY, Foglia TA. Synthesis of Short-/Medium-chain-length poly(hydroxyalkanoates) blends by mixed culture fermentation of glycerol. Biomacromolecules 2005;6:2106-2112.

[44] Koller M, Bona R, Braunegg G, Hermann C, Horvat P, Kroutil M, Martinz J, Neto J, Pereira L, Varila $P$. Production of polyhydroxyalkanoates from agricultural waste and surplus materials. Biomacromolecules 2005;6:561-565.

[45] Solaiman DK, Ashby RD, Foglia TA. Production of polyhydroxyalkanoates from intact triacylglycerols by genetically engineered Pseudomonas. Appl Microbiol Biotechnol 2001;56:664-669.

[46] Tsuge T. Metabolic improvements and use of inexpensive carbon sources in microbial production of polyhydroxyalkanoates. J Bioscience Bioengin 2002;94(6):579-584.

[47] Guezennec J, Rocchicioli F, Macarron-Gomez B, Khedifa N, Dussauze J, Rimbault A. Occurrence of 3-hydroxyalkanoic acids in sediments from the Guaymas basin (Gulf of California). FEMS Microbial Ecol 1998;26:335-344. 
[48] Macarron-Gomez B. Acumucio de poli-b-hydroxialcanoats en tappets microbians del Delta de l'Ebre. Spain: Universita Autonoma Barcelona Ph.D. thesis; 1992. p.89.

[49] Rothermich MM, Guerrero R, Lenz RW, Goodwin S. Characterization, seasonal occurrence and diel fluctuation of Poly-hydroxyalkanoate) in photosynthetic microbial mats. Appl Environ Microbiol 2000;66:4279-4291.

[50] Jiang X, Ramsay JA, Ramsay BA. Acetone extraction of mcl-PHA from Pseudomonas putida KT 2440. J Microbiol Methods 2006;67:212-219.

[51] Simon-Colin C, Raguénès G, Crassous P, Moppert X, Guezennec J. A novel mcl-PHA produced on coprah oil by Pseudomonas geuzennei biovar. tikehau, isolated from a "kopara" mat of French Polynesia. Int J Biol Macromo 2008;43(2):176-181.

[52] Domenek S, Langlois V, Renard E. Bacterial polyesters grafted with poly(ethylene glycol): Behaviour in aqueous media. Pol Degrad and Stab 2007;92:1384-1392.

[53] Renard E, Poux A, Timbart L, Langlois V Preparation of a novel artificial bacterial polyester modified with pendant hydroxyl groups. Biomacromolecules 2005;6:891-896.

[54] Toyoda Y, Thomson LR, Langner A, Craft, NE, Garnett KM, Nichols CR, Cheng KM, Dorey CK. Effect of dietary zeaxanthin on tissue distribution of zeaxanthin and lutein in quail. Invest Ophthalmol Vis Sci 2002;43:1210-1221.

[55] Gale CR, Hall NF, Phillips DI, Martyn CN. Lutein and zeaxanthin status and risk of agerelated macular degeneration. Invest Ophthalmol Vis Sci 2003;44:2461-2465.

[56] Bone RA, Landrum JT, Hime GW, Cains A, Zamor J. Stereochemistry of the human macular carotenoids. Invest Ophthalmol Vis Sci 1993;34:2033-2040. 


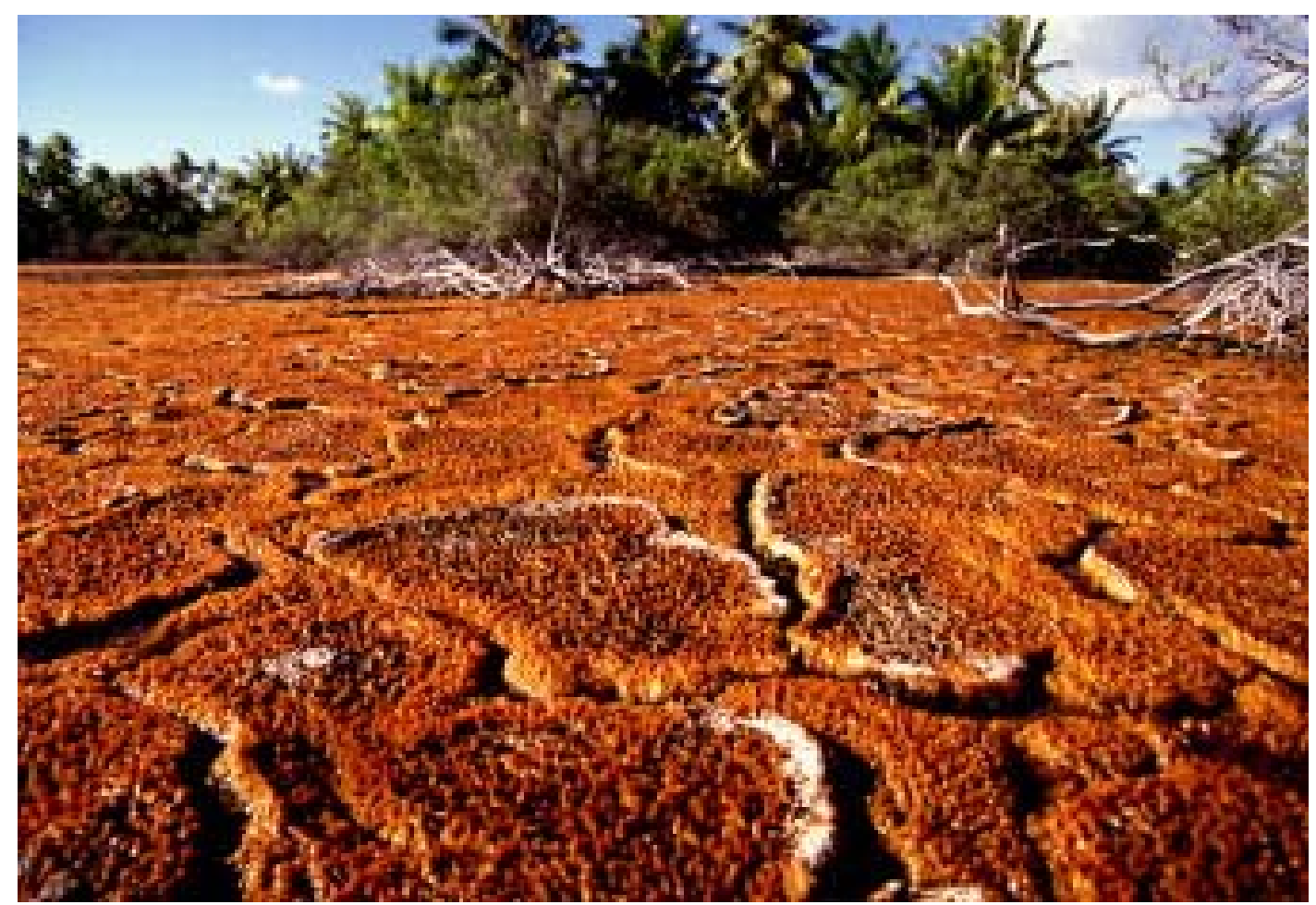

Fig. 1 Microbial mats from Polynesian atolls.

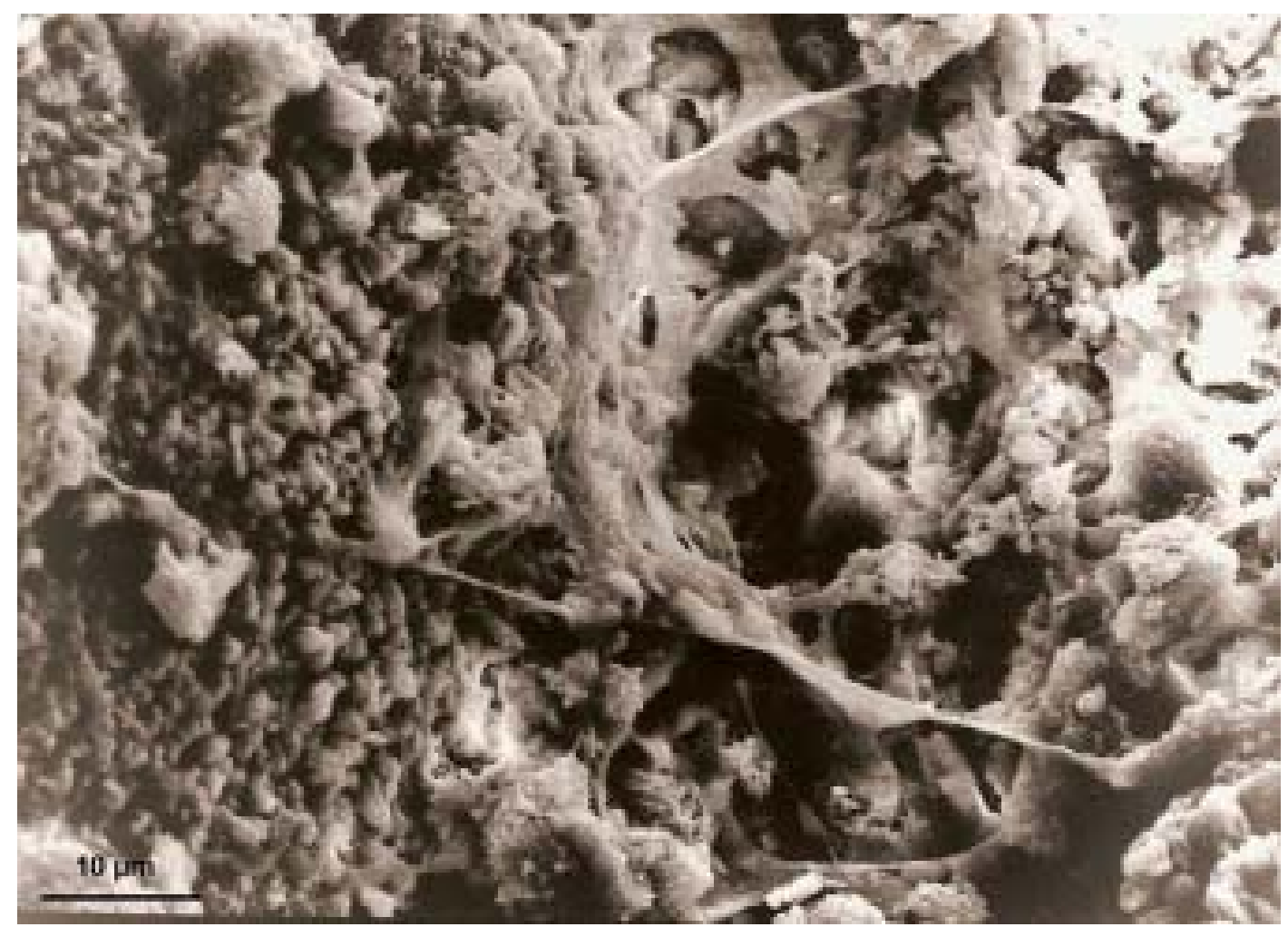

Fig. 2 Scanning electron micrograph of the occurrence of exopolymeric substances within microbial mats. Bar represents $10 \mu \mathrm{m}$. 


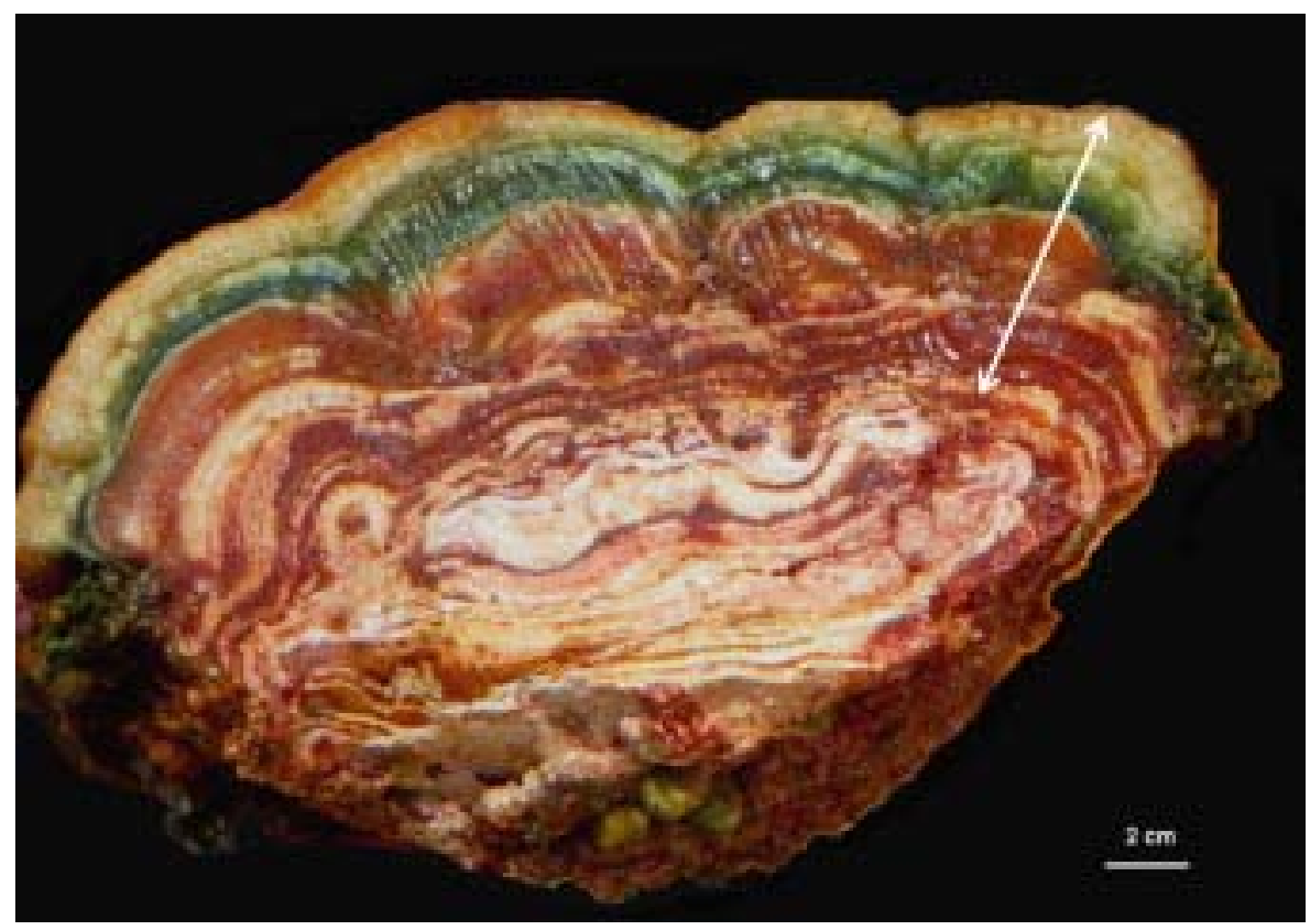

Fig. 3 Microbial stratification within "kopara" mats showing different microbial metabolistic development. White arrow corresponds to high EPS concentration area.

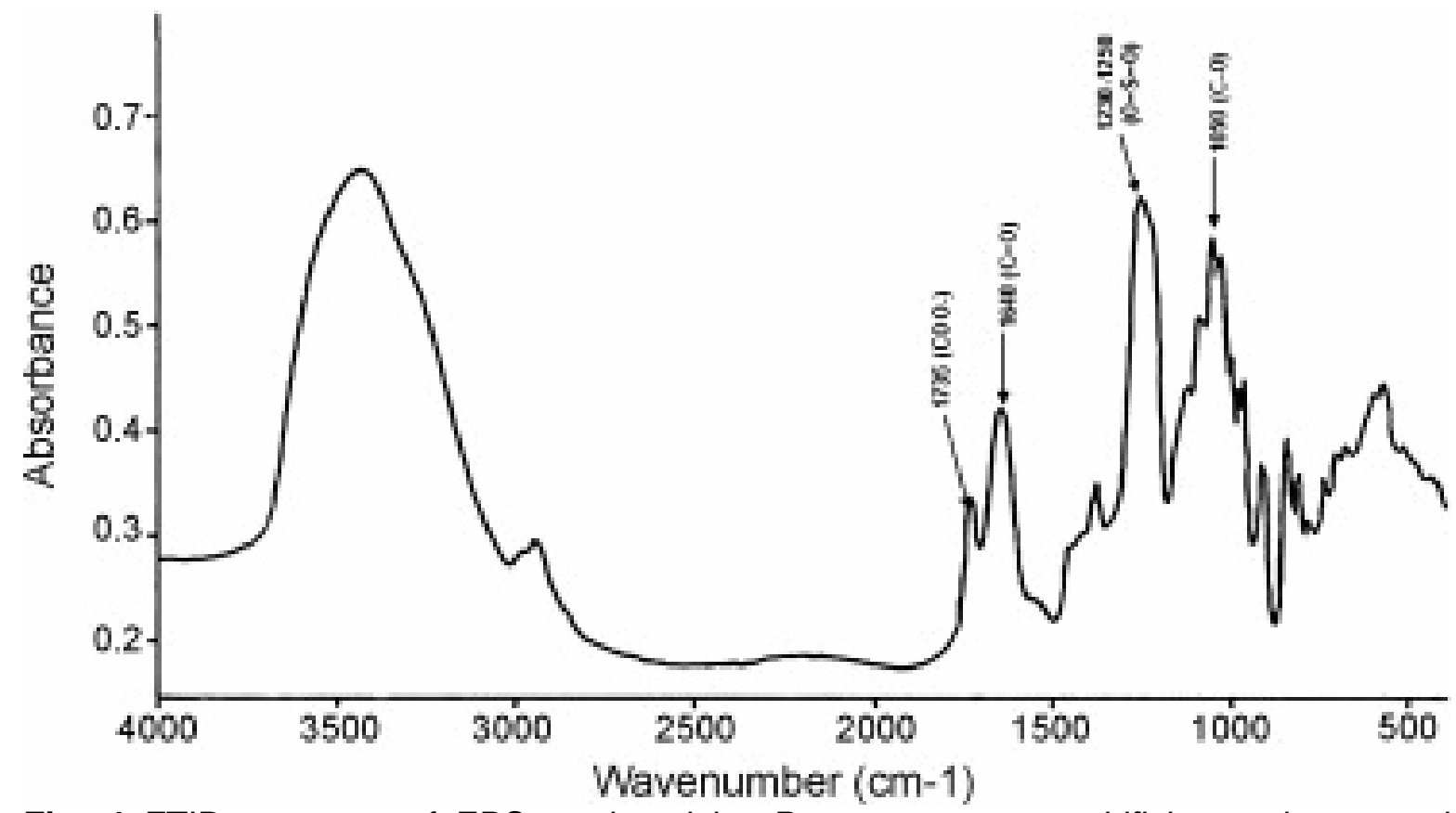

Fig. 4 FTIR spectrum of EPS produced by Paracoccus zeaxanthificiens subsp. payriae describing its main chemical characteristics. 

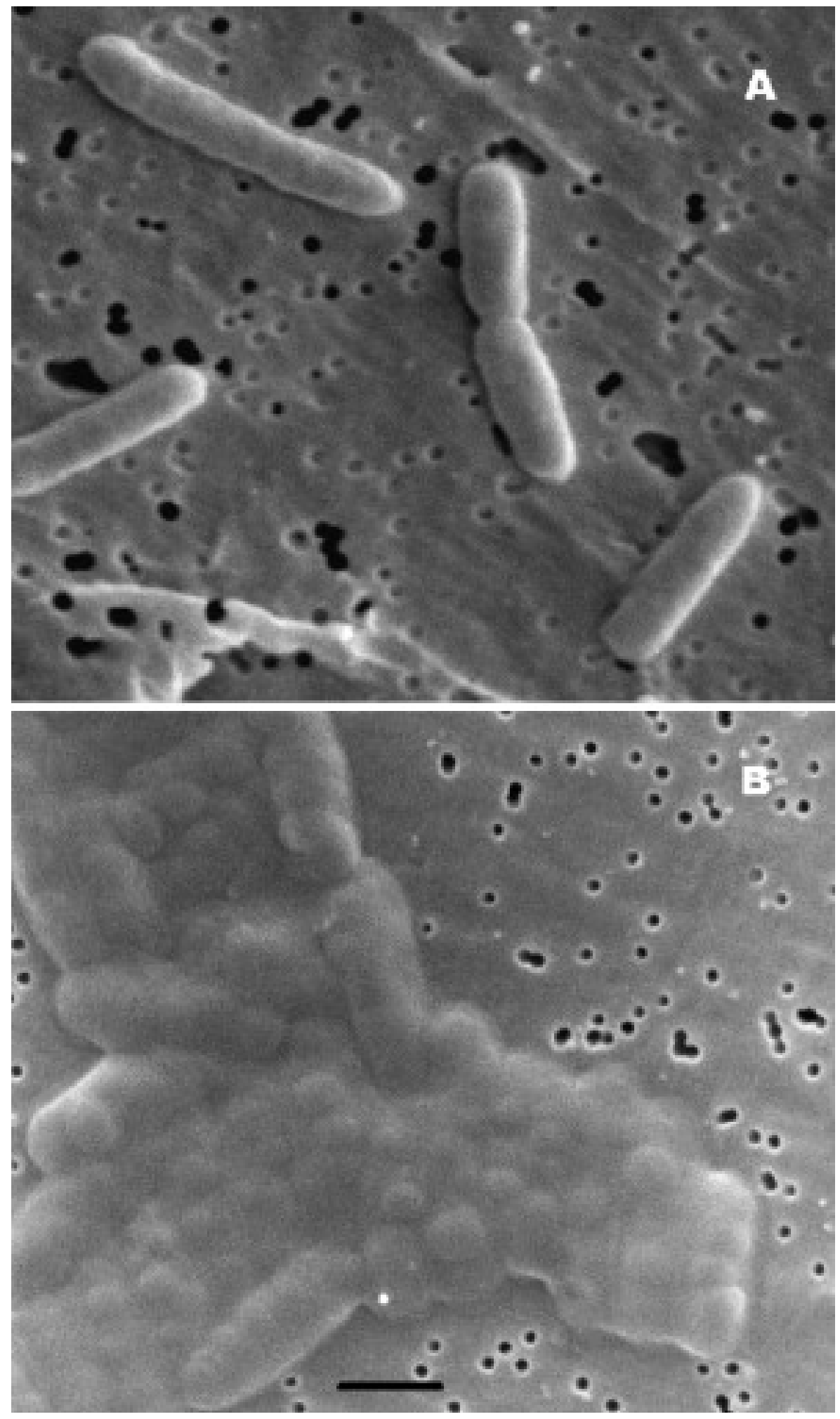

Fig. 5 Scanning electron micrograph of Pseudomona guezennei biovar. tikehau. (A) SEM image of cells in phase division when grown in nitrogen-enriched medium. (B) SEM image of cells after 52 hours in free-nitrogen medium enriched with coprah oil, showing numerous PHAs granules in each cell. Bar represents $1 \mu \mathrm{m}$. 
Table 1. Abundance of the exopolysaccharide fractions of Tetiaroa and Rangiroa mats.

\begin{tabular}{|l|l|l|l|}
\cline { 1 - 1 } Section & Depth $\mathbf{( c m})$ & Abundance mg/g dry \\
\cline { 1 - 1 } IT1 & $0-1$ & 26.8 \\
\hline IT1' + IT2 & $1-6$ & 11.2 \\
\hline IT3 + IT4 & $6-13$ & 4.3 \\
\hline IT5 & $13-19$ & 4.5 \\
\hline R2-1 & $0-2.7$ & 46.8 \\
\hline R2-2 & $2.7-4.5$ & 9.4 \\
\hline R2-3 & $4.5-8$ & 1 \\
\hline R2-4 & $8-13.7$ & 0 \\
\hline R2-5 & $13.7-18.5$ & 0 \\
\hline R9 & $0-2.5$ & 25.1 \\
\hline R9 P & $0-2.9$ & 48.2 \\
\hline R9 G & $0-3.1$ & 37.1 \\
\hline
\end{tabular}


Table 2. Polynesian EPS composition.

\begin{tabular}{|c|c|c|c|c|c|c|c|}
\hline EPS & Strains & Proteins & Neutrals sugars & Uronic acids & Hexosamines & Sulfates & Substituents \\
\hline RA 1 & $\mathrm{Nd}$ & 3 & 24 & 15 & 16 & - & Lac \\
\hline RA 11 & $\mathrm{Nd}$ & 6 & 28 & 8 & 8 & 10 & Ac, Pyr \\
\hline RA 19 & Paracoccus sp & 3 & 48 & 8 & - & 29 & Ac \\
\hline RA 29 & Vibrio sp & 8 & 44 & 8 & - & 21 & $A c$ \\
\hline TE 7 & Pseudomonas sp & 8 & 38 & 14 & 2 & 8 & Lac \\
\hline Tik 574 & $\mathrm{Nd}$ & 9 & 28 & 22 & & 5 & \\
\hline Tik 650 & Alteromonas sp & 4 & 47 & 10 & & 12 & \\
\hline Tik 668 & $\mathrm{Nd}$ & 7 & 49 & 28 & & 5 & \\
\hline Tik 725 & Alteromonas sp & 7 & 20 & 17 & & - & \\
\hline Mi 550 & Pseudomonas sp & 5 & 34 & 18 & & - & \\
\hline Mo 245 & Vibrio sp & 2 & 11 & 27 & 30 & - & Ac \\
\hline Mo 203 & Alteromonas sp & 4 & 46 & 20 & - & - & \\
\hline
\end{tabular}

Lac, lactate; Ac, acetate; Pyr, pyruvate. 